\title{
Anal Pap Smear
}

National Cancer Institute

\section{Source}

National Cancer Institute. Anal Pap Smear. NCI Thesaurus. Code C93017.

The collecting of secretions and superficial cells of the anus, which are then examined with a microscope to detect any abnormal cells. 